\title{
Apex cardiogram and systolic time intervals in acute myocardial infarction
}

\author{
S. R. Jain ${ }^{1}$ and J. Lindahl \\ From the Department of Clinical Physiology, Karolinska Sjukhuset, Stockholm, Sweden
}

Simultaneous recordings of apex cardiogram, phonocardiogram, indirect carotid pulse, and electrocardiogram were made in 12 patients with acute myocardial infarction and in 12 normal subjects of comparable age.

The apex cardiogram showed in the patients increased amplitude and duration of the ' $a$ ' wave and in 40 per cent a notching. Half of the cases had a flat systolic plateau and over 80 per cent a systolic 'bulge'.

The a-E interval and the time to the systolic peak of the apex cardiogram were significantly shortened. The systolic time intervals showed shortening of the pre-ejection period $I$, isovolumetric contraction time, electromechanical systole, and ejection time along with the E-F interval which represents the phase of maximum ventricular ejection. The changes observed were thought to be due to an increase in circulating catecholamines. Estimation of the urinary excretion of adrenaline and noradrenaline in two cases showed three times normal values.

Apex cardiography is a technique for recording low frequency praecordial movements. It was introduced by Marey as early as 1863 but was not generally used until about two decades ago. Since then it has been studied in different heart diseases, e.g. mitral valvular disease (Benchimol et al., 1960), hypertrophic subaortic stenosis (Wolfe, I966), angina pectoris (Dimond and Benchimol, I963), ischaemic heart disease (Benchimol and Dimond, I962; Rörvik, 1963), and left ventricular aneurysm (Ahuja, Gutierrez, and Manning, 1967), but its value in acute myocardial infarction has so far not been explored. Apex cardiograms, phonocardiograms, and indirect carotid pulse tracings are now being commonly used to time the various systolic time intervals (Oreshkov, 1968; Spodick and Kumar, 1968). These are thought to give information about myocardial function from studies on patients with heart failure (Weissler, Harris, and Schoenfeld, 1968), hypertension, coronary heart disease, cardiomyopathy, etc. (Tarazi, Frohlich, and Dustan, 1969; Weissler, Harris, and Schoenfeld, 1969). The purpose of this work is to study the apex cardiogram and systolic time intervals during the early stage of acute myocardial infarction.

Received 16 November 1970.

1 Present address: M.G.M. Medical College and M.Y. Group of Hospitals, Indore, India.

\section{Subjects}

Ten male and 2 female patients with an average age of 62 years (range 49-73) admitted to a coronary care unit with acute myocardial infarction proved by electrocardiogram and/or enzyme changes were studied within 48 hours of onset of chest pain. Cases with a past history of infarction, or complications, e.g. cardiac failure, shock, arrhythmias (except premature beats), or electrolyte disturbances, or receiving drugs likely to affect myocardial contractility, e.g. digitalis, quinidine, and $\beta$-receptor blocking drugs have been excluded. Seven cases did receive lignocaine in the dose of $1 \mathrm{mg} / \mathrm{min}$ which, however, does not affect myocardial function significantly (Binnion et al., 1969). Eight male and 4 female normal healthy volunteers of comparable age (average 45 years, range 32-56) were also studied as controls. They were chosen on the basis of absence of history of any disease, normal physical examination, a normal electrocardiogram, and exercise test (Sjöstrand, 1960).

\section{Methods}

Apex cardiogram, phonocardiogram, indirect carotid pulse tracing, and a reference electrocardiogram (usually lead II) were recorded simultaneously on a 6-channel electrocardiograph (Minograph 8I, Elema-Schönander, Stockholm) at a paper speed of $100 \mathrm{~mm} / \mathrm{sec}$. The procedure for recording the apex cardiogram was as described by Benchimol and Dimond (I963), using an APT I6 transducer (Hewlett-Packard, Palo Alto, California). The same equipment was used also for 
indirect carotid pulse recording. Analysis of the tracings was tabulated from an average of 5 consecutive cardiac cycles each read to the nearest 5 msec.

The following definitions have been used (Fig. I):

Electromechanical delay

Pre-ejection period I

(Tafur, Cohen, and

Levine, 1964)

Pre-ejection period II

(Tafur et al., 1964)

Ejection time (ET)

Electromechanical systole (EMS)

Mechanical systole

Pulse transmission time (PTT)

Isovolumetric contraction time (Spodick and

Kumar, 1968)

Isovolumetric relaxation time

Tension period (Margolis, I964; called pre-ejection period by e.g. Weissler et al., 1968, I969)

Rapid filling wave

Diastolic filling wave
Q-ACG

$\mathrm{ACG}_{\mathrm{u}}-\mathrm{M}_{1}$

$M_{1}-C R_{u}$ $\mathrm{CAR}_{\mathrm{u}}-\mathrm{DN}$

Q-A

$\mathbf{M}_{1}-A_{2}$

$\mathrm{A}_{2}-\mathrm{DN}$

$\mathrm{ACG}_{\mathrm{u}}-\mathrm{CAR}_{\mathrm{u}}$ minus PTT

$$
\mathrm{A}_{2}-\mathrm{O}
$$

EMS minus ET

O-F

O-peak of ' $a$ ' wave

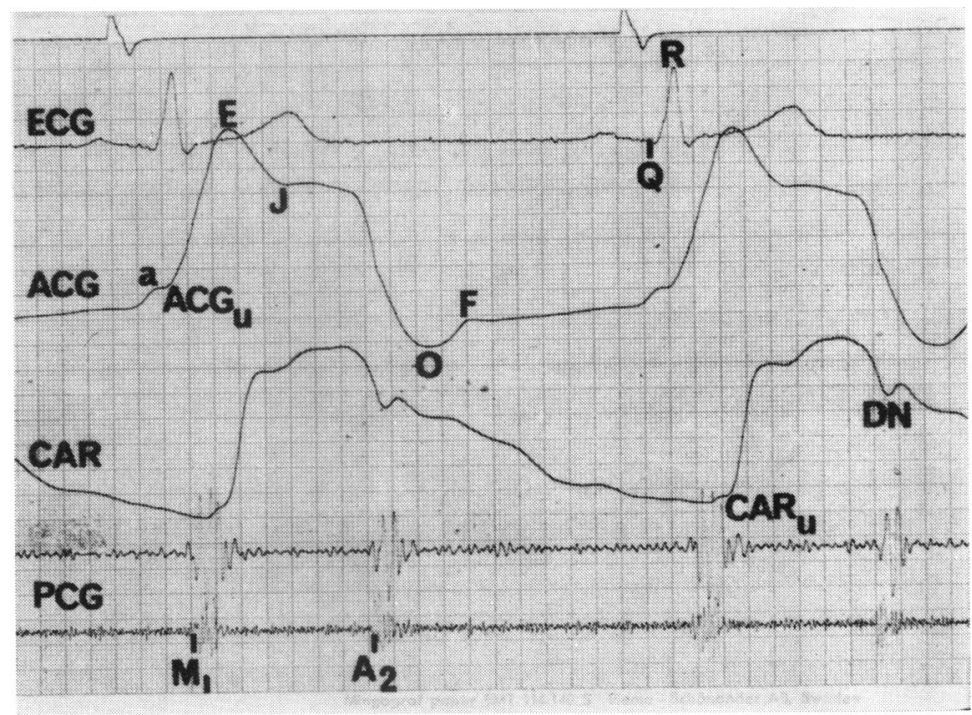

FIG. I Simultaneous electrocardiogram, apex cardiogram, carotid pulse, and phonocardiogram from a normal subject showing the reference points. $A C G_{u}=u$ pstroke of the apex cardiogram; $C A R_{u}$ and $D N=u p s t r o k e$ and dicrotic notch of the carotid pulse tracing.

lateral 'bulge' (Table 2). A diastolic 'bulge' was not present in any of the subjects studied.

intervals are expressed in milliseco ' $a$ ' wave, rapid filling wave, and diastolic filling wave ratios were calculated as percentage of maximum amplitude of the apex cardiogram, i.e. E-O height. The criteria of Rörvik (1963) have been taken to define the systolic plateau. Statistical calculations were performed according to Snedecor (1959).

\section{Results}

Heart rate and blood pressure Mean values for heart rate and blood pressure were 69 beats/min and $124 / 76 \mathrm{mmHg}$ in the control group and 78 beats/min and $136 / 78 \mathrm{mmHg}$ in the myocardial infarction group.

Apex cardiogram The patients with myocardial infarction had a significant increase in amplitude as well as duration of the ' $a$ ' wave (Table I). Five patients in this group had notching of the ' $a$ ' wave compared to none in the control group. The rapid filling wave ratio was the same in both groups and the increase in diastolic filling wave ratio in the myocardial infarction group was possibly due to the increased amplitude of the ' $a$ ' wave.

Half of the infarction group showed a flat systolic plateau compared to none in the controls. A systolic 'bulge' was present in ro of the patients with myocardial infarction and in 2 of the controls, both of whom also had a
Time intervals The time intervals $a-E$, $A C G_{u}-E$, and $R-E$ showed a significant re(Table 3). The latter interval was also measured because the upstroke point of the apex cardiogram is sometimes not clearly defined, especially when the ' $a$ ' wave is fused with it. Usually the peak of the ' $R$ ' wave in the electrocardiogram coincides with the apex cardiogram upstroke. The similarity of the two intervals is clear (Table 3).

Pre-ejection period I and the isovolumetric contraction time were significantly shorter in

TABLE I Features of diastolic wave of apex cardiogram (mean $\pm S D$ )

\begin{tabular}{|c|c|c|c|c|c|}
\hline & \multicolumn{3}{|l|}{ ' $a$ ' wave } & \multirow{2}{*}{$\begin{array}{l}\text { Rapid } \\
\text { filling } \\
\text { wave }\end{array}$} & \multirow{2}{*}{$\begin{array}{l}\begin{array}{l}\text { Diastolic } \\
\text { filling } \\
\text { wave }\end{array} \\
\begin{array}{l}\text { Amplitude } \\
\text { ratio }(\%)\end{array}\end{array}$} \\
\hline & $\begin{array}{l}\text { Amplitude } \\
\text { ratio (\%) }\end{array}$ & $\begin{array}{l}\text { Duration } \\
\text { (msec) }\end{array}$ & $\begin{array}{l}\text { Shape } \\
\text { (notching) }\end{array}$ & & \\
\hline $\begin{array}{l}\text { Controls } n=12 \\
\text { Myocardial infarc- } \\
\text { tion } n=12\end{array}$ & $\begin{array}{c}7 \pm 3 \\
19 \pm 15\end{array}$ & $\begin{array}{l}65 \pm 16 \\
88 \pm 14\end{array}$ & $\begin{array}{l}0 \\
5\end{array}$ & $\begin{array}{l}17 \pm 6 \\
16 \pm 7\end{array}$ & $\begin{array}{l}28 \pm 9 \\
38 \pm 19\end{array}$ \\
\hline $\mathbf{P}$ value & $<0.02$ & $<0.01$ & & & \\
\hline
\end{tabular}
duction in the myocardial infarction group 
TABLE 2 Changes in systolic wave of apex cardiogram

\begin{tabular}{|c|c|c|c|c|c|c|c|c|}
\hline & \multicolumn{2}{|c|}{ Systolic plateau } & \multicolumn{5}{|c|}{ Systolic 'bulge' } & \multirow{2}{*}{$\begin{array}{l}\text { Flat plateau } \\
\text { and 'bulge' }\end{array}$} \\
\hline & $\begin{array}{l}\text { Normal } \\
<80 \% \\
\quad \text { of } E-O\end{array}$ & $\begin{array}{l}\text { Flat } \\
>80 \% \\
\text { height }\end{array}$ & $\begin{array}{l}\text { Pan- } \\
\text { systolic }\end{array}$ & Double & $\begin{array}{l}\text { Mid- } \\
\text { systolic }\end{array}$ & Lateral & Total & \\
\hline Controls $n=12$ & 12 & ० & - & - & - & 2 & 2 & o \\
\hline $\begin{array}{l}\text { Myocardial infarction } \\
\mathrm{n}=12\end{array}$ & 6 & 6 & 4 & $\mathbf{I}$ & $\mathbf{I}$ & 4 & 10 & 5 \\
\hline
\end{tabular}

TABLE 3 Systolic and diastolic time intervals (msec; mean $\pm S D$ )

\begin{tabular}{|c|c|c|c|c|c|c|c|c|c|}
\hline & $a-E$ & $A C G_{u}-E$ & $R-E$ & $\begin{array}{l}\text { Electro- } \\
\text { mechani- } \\
\text { cal delay }\end{array}$ & $\begin{array}{l}\text { Pre- } \\
\text { ejection } \\
\text { period I }\end{array}$ & $\begin{array}{l}\text { Pre- } \\
\text { ejection } \\
\text { period II }\end{array}$ & $\begin{array}{l}\text { Iso- } \\
\text { volu- } \\
\text { metric } \\
\text { contrac- } \\
\text { tion } \\
\text { time }\end{array}$ & $\begin{array}{l}\text { Pre- } \\
\text { ejection } \\
\text { period II } \\
\text { minus } \\
\text { pulse } \\
\text { trans- } \\
\text { mission } \\
\text { time }\end{array}$ & $\begin{array}{l}\text { Isovolu- } \\
\text { metric } \\
\text { relaxa- } \\
\text { tion } \\
\text { time }\end{array}$ \\
\hline $\begin{array}{c}\text { Controls } \\
n=12\end{array}$ & $150 \pm 15$ & $113 \pm 15$ & $109 \pm 15$ & $31 \pm 9$ & $38 \pm 10$ & $57 \pm 13$ & $78 \pm 15$ & $40 \pm 10$ & $100 \pm 25$ \\
\hline $\begin{array}{c}\text { Myocardial } \\
\text { infarction } \\
\mathbf{n}=12\end{array}$ & $108 \pm 47$ & $78 \pm 19$ & $83 \pm 21$ & $38 \pm 15$ & $28 \pm 14$ & $45 \pm 15$ & $62 \pm 14$ & $35 \pm 12$ & $115 \pm 19$ \\
\hline$P$ value & $<0.01$ & $<0.001$ & $<0.001$ & & $<0.05$ & & $<0.02$ & & \\
\hline
\end{tabular}

the myocardial infarction group, but there were no significant differences in electromechanical delay, pre-ejection period 2, and isovolumetric relaxation time compared to controls (Table 3 ).

The mean values for electromechanical systole, ejection time, and tension period in the groups are presented in Table 4 . In the normal subjects these time intervals were related to heart rate according to the following regression equations: $\mathrm{EMS}=539-2 \cdot 00 \mathrm{HR}$ $(\mathrm{SD} \pm \mathrm{I5} .9), \mathrm{ET}=403-\mathrm{I} .59 \mathrm{HR}(\mathrm{SD} \pm 7.4)$, $\mathrm{TP}=135-0.4 \mathrm{I}$ HR $(\mathrm{SD} \pm 12.4)$, which do

TABLE 4 Electromechanical systole, ejection time, and tension period (mean $\pm S D$ ): mean values calculated from individual values corrected to heart rate 70 beats/min

\begin{tabular}{|c|c|c|c|}
\hline & $\begin{array}{l}\text { Electro- } \\
\text { mechanical } \\
\text { systole } \\
\text { (msec) }\end{array}$ & $\begin{array}{l}\text { Ejection } \\
\text { time } \\
\text { (msec) }\end{array}$ & $\begin{array}{l}\text { Tension } \\
\text { period } \\
\text { (msec) }\end{array}$ \\
\hline $\begin{array}{c}\text { Controls } \\
n=12\end{array}$ & $399 \pm 14$ & $293 \pm 7$ & $106 \pm$ II \\
\hline $\begin{array}{c}\text { Myocardial } \\
\text { infarction } \\
n=12\end{array}$ & $379 \pm 18$ & $274 \pm 21$ & $104 \pm 16$ \\
\hline $\mathbf{P}$ values & $<0.01$ & $<0.01$ & \\
\hline
\end{tabular}

not significantly differ from those of Weissler et al. (1969), and Spodick, Dorr, and Calabrese (1969). Fig. 2 shows the regression lines and the individual values of electromechanical systole and ejection time. Both electromechanical systole and ejection time were significantly shortened in patients with myocardial infarction. The tension period showed no significant difference.

\section{Discussion}

The ' $a$ ' wave The ' $a$ ' wave ratio of 7 per cent $( \pm 3)$ in controls does not differ from that of other investigators (Benchimol and Dimond, 1962; Rios and Massumi, 1965; Epstein et al., 1968). In acute infarction the mean ratio was 19 per cent $( \pm 15)$ but a ratio above 20 per cent was present in 4 patients only. There were 2 patients who gave a past history of hypertension but were normotensive at the time of the study, including one with slight enlargement of the heart (volume 530 $\mathrm{ml} / \mathrm{m}^{2}$ ) and an ' $a$ ' wave ratio of II per cent. The heart size was normal clinically and radiologically in the remaining II patients. This low incidence of truly abnormal ' $a$ ' wave ratio was possibly due to the selection of the material. However, this study confirms the observation of Benchimol and Dimond (1962) that, excluding left ventricular hypertrophy 


\section{-Control \\ - Myocardial Infarction}

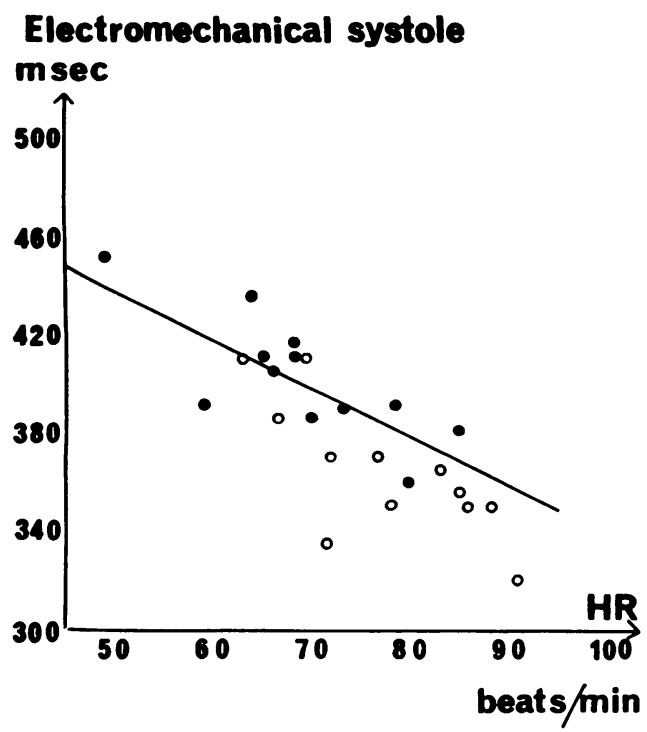

\section{Ejection time} m sec

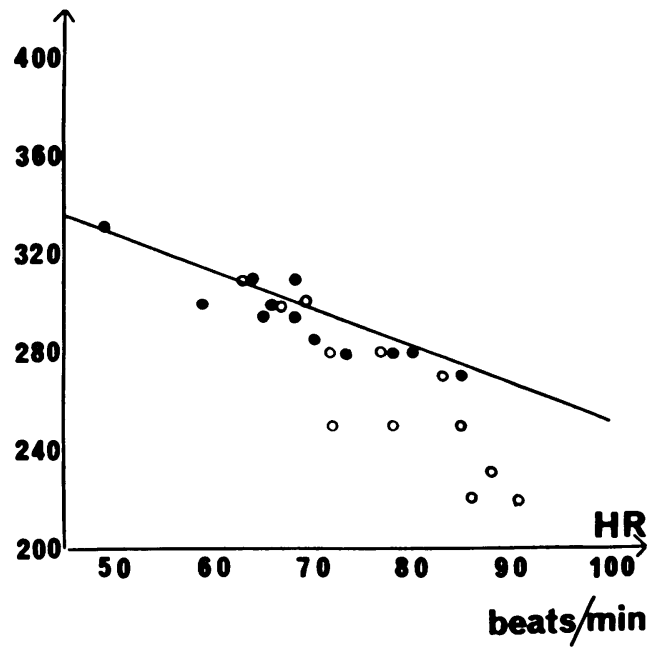

FIG. 2 Electromechanical systole and ejection time in acute myocardial infarction compared to controls plotted on normal regression lines.

and failure, increased ' $a$ ' wave ratio is present in ischaemic heart disease due to restricted myocardial distensibility.

Notching of the ' $a$ ' wave (Fig. 3) was present in 5 patients with infarction. All were associated with a fourth heart sound which was present, however, in a total of 7 patients. The type of infarct in all the 5 patients was anterior, though in 2 of them changes in leads II, III, and aVF of progressive nature were also seen. Notched ' $a$ ' waves have been reported in cases of ischaemic heart disease by Benchimol and Dimond (1962) but no incidence was given. These authors did not observe notched ' $a$ ' waves in their study of normal subjects or in 15 patients with hypertension and ro with angina pectoris. This high incidence $(40 \%)$ in acute infarction will need further observations for evaluation.

Systolic wave A flat systolic plateau was not observed in any of the controls while it was present in half the patients with acute infarction. It has been reported in ischaemic heart disease by Rörvik (1963) who distinguished normal high, mid, and low plateau from abnormal flat and pansystolic plateau.

Systolic 'bulge' (Fig. 4) was present in over 80 per cent of the patients with acute infarction. Lateral 'bulge' may be present in normal subjects occasionally (Benchimol and
Dimond, 1963), but the height of the 'bulge' in both the control subjects was less than 15 per cent of E-O height. In contrast the height of the lateral systolic 'bulge' in infarction was above 30 per cent, and hence the height of the lateral 'bulge' may be a guide in distinguishing them. Midsystolic, pansystolic, and double 'bulges' were not seen in any of the controls. McGinn, Gould, and Lyon (1968) observed systolic 'bulges' in only 12 of 56 cases of old myocardial infarction. Lane et al. (1968) studied 4I proved cases of myocardial asynergy and observed a systolic 'bulge' in 30 cases. The high incidence of systolic 'bulge' in the present study confirms the observations of other workers that myocardial asynergy is much more common during the acute phase. However, the systolic 'bulge' was present in the follow-up apex cardiograms two weeks later in all cases except one (Fig. 4). Flat systolic plateau and systolic 'bulge' have also been reported in cases of left ventricular hypertrophy, but the cause is not known.

Time intervals The a-E and $A_{C G}-E$ intervals were significantly shortened in the patients with myocardial infarction. Benchimol and Dimond (1962) reported a prolongation of the a-E interval in ischaemic heart disease but their patients may not have been studied at an early enough myocardial infarct 


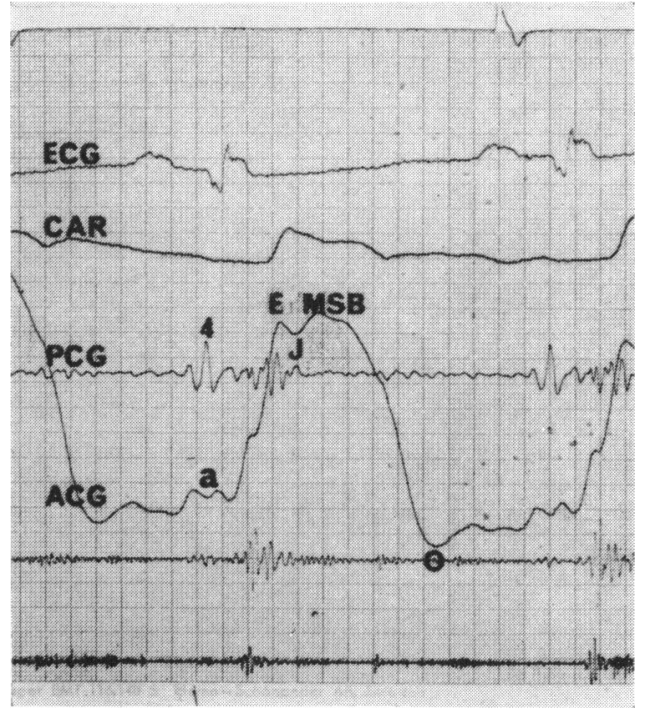

FIG. 3 Tracings from a patient with acute myocardial infarction showing notched ' $a$ ' wave in the apex cardiogram and fourth heart sound in the phonocardiogram. $M S B=$ midsystolic bulge.

stage. The ' $a$ ' wave duration in our patients (Table I) was prolonged, however, as also reported by Benchimol and Dimond (1962). It appears that shortening of a-E interval is due to shortening of $A C G_{u}-E$ interval, which represents time to the systolic peak of the apex cardiogram. Reale (1967) has shown that this correlates well with time to peak dp/dt. Mason et al. (1965) have shown that the latter is inversely proportional to myocardial contractility and is not affected by preload and afterload. The shortening of $\mathrm{ACG}_{\mathrm{u}}-\mathrm{E}$ thus suggests a compensatory increase in myocardial contractility.

In acute infarction all systolic time intervals (Tables 3 and 4) were decreased except electromechanical delay which was slightly increased. A shortened ejection time has been reported in acute infarction (Ježek, 1963) and also in coronary heart disease (Weissler et al., 1969), and has been used as an index of cardiac function (Spodick et al., 1969). The present study confirms the above observations and also that of Toutouzas et al. (1969) who reported shortening of the Q- $\mathrm{A}_{2}$ interval (electromechanical systole) during the acute phase of myocardial infarction. Pre-ejection period I and isovolumetric contraction time were significantly shortened in the present series. Prolongation of the isometric contraction phase (pre-ejection period II minus pulse transmission time) in acute infarction and of tension period in coronary artery disease have been reported by Ježek (1963) and Weissler et al. (1969), respectively. These two intervals were not significantly affected in the present study. However, the results may not be comparable, as their cases may not have been studied during the first $\mathbf{4 8}$ hours of infarction. Ježek (1963) did remark that the prolongation was not regularly seen and thought it was due to an abnormal myocardial contraction.

The observations of the present study and those of others show that the myocardium behaves differently in the first $\mathbf{4 8}$ hours of an acute myocardial infarction compared with chronic ischaemic heart disease. The shortening of pre-ejection period $I$, isovolumetric contraction time, electromechanical systole, ejection time, a-E and $\mathrm{ACG}_{\mathrm{u}}-\mathrm{E}$ intervals are suggestive of an increased inotropic influence on the myocardium possibly due to circulating catecholamines, which are known to be increased in these cases (Richardson, 1963; Valori, Thomas, and Shillingford, 1967; Wallace, 1968).

In two cases of the present series the urinary excretion of adrenaline and noradrenaline measured on the day of recording showed values about three times normal. Reale (1967) has shown reduction in time to the systolic

FIG. 4 Tracings showing a prominent ' $a$ ' wave, mid-and lateral systolic bulge (MSB and $L S B$ ) in a case of acute myocardial infarction (left), and the tracings of the same patient 15 days later showing a normal apex cardiogram (right).

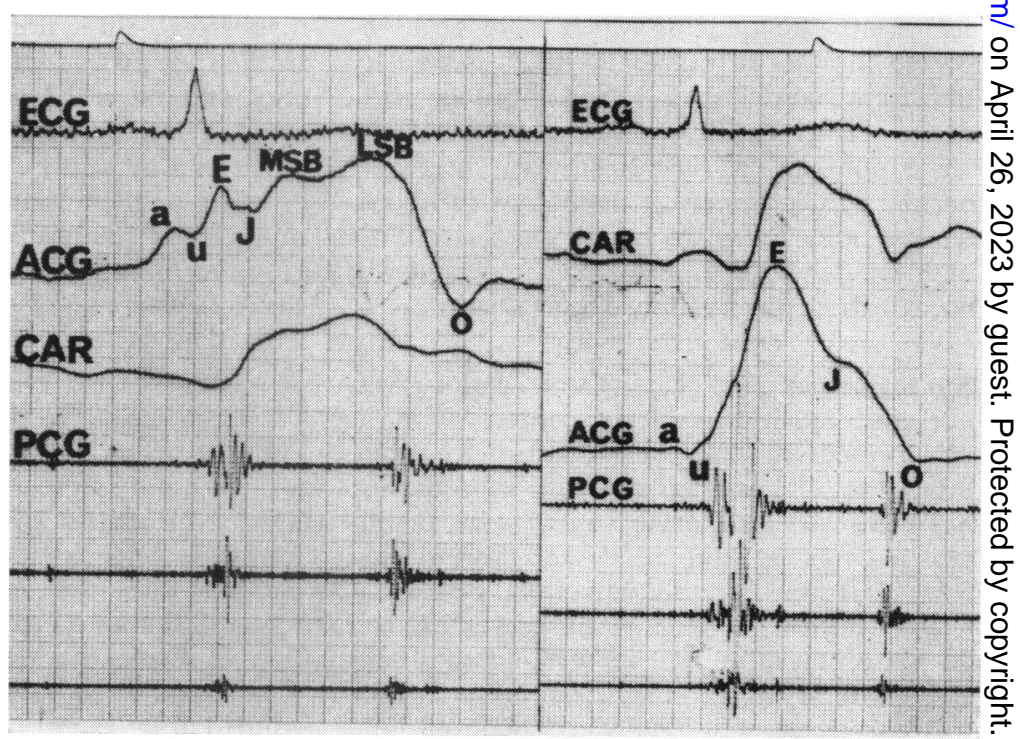


peak of the apex cardiogram by orciprenaline infusion and lengthening by beta-blockade.

Braunwald, Sarnoff, and Stainsby (1958) have shown that catecholamines cause an increase in the mean rate of ejection. The apex cardiograms were restudied to see if any information could be gained. A normal apex cardiogram shows a descent from the $\mathrm{E}$ point ending in a plateau and another descent just before closure of the aortic valves to end in the $O$ point (Fig. I). The first descent corresponds to the maximum ejection phase of the ventricle (Benchimol and Dimond, 1963). The point at which the descent ends and the plateau begins has been designated as the $J$ point. The E-J interval was measured and expressed as percentage of mechanical systole and ejection time in Table 5. The E-J interval was shortened in relation to the mechanical systole and the ejection time, i.e. a steeper descent from the $E$ point to the $J$ point in acute infarction compared to controls. As the E-J interval represents indirectly the maximum ejection phase, the above observation supports the belief that the increase in the ejection rate may possibly be due to catecholamines. If this is so, the E-J interval of the apex cardiogram, a new parameter so far unexplored, will be a useful guide to the ejection rate, but further confirmation will be necessary with haemodynamic data, etc., of these preliminary observations.

The investigations were repeated 2 to 3 weeks after admission to hospital, but, except for 5 cases, all had received digitalis therapy during the treatment period. Table 6 shows the mean time intervals in these 5 cases at the first and second examination. The intervals which were shortened on admission had almost returned to normal suggesting reduced catecholamine influence. Wallace (1968) reported that the urinary catecholamine excretion decreased in a stepwise manner during the first Io days in hospital.

The strong adrenergic drive in acute myocardial infarction, particularly when there is circulatory failure, with increased blood catecholamine levels, is possibly responsible for
TABLE 5 Mean E-F interval expressed as percentage of mechanical systole (MS), and ejection time $(E T):(E-\mathcal{F}, M S$, and $E T$ not corrected for heart rate)

\begin{tabular}{llllll}
\hline & $E-\mathcal{F}$ & $\begin{array}{l}\text { Mechanical } \\
\text { systole } \\
(\mathrm{msec})\end{array}$ & $\frac{E-\mathcal{F}}{M S} \times 100$ & $\begin{array}{l}\text { Ejection } \\
\text { time } \\
(\mathrm{msec})\end{array}$ & $\frac{E-\mathcal{F}}{E T} \times 100$ \\
\hline $\begin{array}{l}\text { Controls n=12 } \\
\begin{array}{l}\text { Myocardial infarction } \\
\text { n=12 }\end{array}\end{array}$ & $\mathbf{1 5 5}$ & 332 & 60 & 294 & 53 \\
\hline
\end{tabular}

the changes in the apex cardiogram and systolic time intervals. Whether this overactivity of the sympathetic nervous system represents a beneficial or detrimental response, however, is something that will need further study.

We are grateful to the National Association against Heart and Lung Diseases for awarding a research scholarship in cardiology to one of us (S.R.J.), and wish to thank Dr. G. C. Sepaha, Professor and head of the Department of Medicine, M.G.M. Medical College, Indore, India, for stimulating interest in atraumatic procedures for studying cardiac function, and to Professor T. Sjöstrand and Associate Professor L. G. Ekelund for advice and valuable criticism during the study and in the preparation of the manuscript.

\section{References}

Ahuja, S. P., Gutierrez, M. R., and Manning, G. W. (1967). Value of apex cardiography in the assessment of cardiac aneurysms. American fournal of Cardiology, 19, 464.

Benchimol, A., and Dimond, E. G. (1962). The apex cardiogram in ischaemic heart disease. British Heart fournal, 24, 581.

Benchimol, A., and Dimond, E. G. (1963). The normal and abnormal apexcardiogram; its physiologic variation and its relation to intracardiac events. American fournal of Cardiology, 12, 368.

Benchimol, A., Dimond, E. G., Waxman, D., and Shen, Y. (1960). Diastolic movements of the precordium in mitral stenosis and regurgitation. American Heart fournal, 60, 417.

Binnion, P. F., Murtagh, G., Pollock, A. M., and Fletcher, E. (1969). Relation between plasma lignocaine levels and induced haemodynamic changes. British Medical fournal, 3, 390.

TABLE 6 Mean time intervals (msec) on admission and after 2 weeks in 5 patients who did not receive digitalis therapy

\begin{tabular}{llllllll}
\hline & $\begin{array}{l}\text { Heart } \\
\text { rate }\end{array}$ & $\begin{array}{l}\text { Pre-ejection } \\
\text { period I }\end{array}$ & $\begin{array}{l}\text { Pre-ejection } \\
\text { period II }\end{array}$ & $\begin{array}{l}\text { Isovolu- } \\
\text { metric } \\
\text { contraction } \\
\text { time }\end{array}$ & $\begin{array}{l}\text { Ejection } \\
\text { time (corr.) }\end{array}$ & $\begin{array}{l}\text { Electro- } \\
\text { mechanical } \\
\text { systolic } \\
\text { (corr.) }\end{array}$ \\
\hline $\begin{array}{l}\text { On admission } \\
\text { After 2 weeks }\end{array}$ & 74 & 24 & 44 & 58 & 291 & 411 \\
\end{tabular}


Braunwald, E., Sarnoff, S. J., and Stainsby, W. N. (1958). Determinants of duration and mean rate of ventricular ejection. Circulation Research, 6, 319.

Dimond, E. G., and Benchimol, A. (1963). The exercise apexcardiogram in angina pectoris: its possible usefulness in diagnosis and therapy. Diseases of the Chest, 43, 92.

Epstein, E. J., Coulshed, N., Brown, A. K., and Doukas, N. G. (1968). The ' $A$ ' wave of the apex cardiogram in aortic valve disease and cardiomyopathy. British Heart fournal, 30, 59r.

Ježek, V. (1963). Clinical value of the polygraphic tracing in the study of the sequence of events during cardiac contraction. Cardiologia, 43, 298.

Lane, F. J., Carroll, J. M., Levine, H. D., and Gorlin, R. (1968). The apexcardiogram in myocardial asynergy. Circulation, 37, 890.

McGinn, F. X., Gould, L., and Lyon, A. F. (1968). The phonocardiogram and apexcardiogram in patients with ventricular aneurysm. American fournal of Cardiology, 21, 467.

Margolis, C. (1964). The significance of ejection period/tension period as a factor in the assessment of cardiac function and as a possible diagnostic tool for the uncovering of silent coronary heart disease. A study of II I cases. Diseases of the Chest, 46, 706.

Mason, D. T., Sonnenblick, E. H., Ross, J., Covell, J. W., and Braunwald, E. (1965). Time to peak $\mathrm{dp} / \mathrm{dt}$ : a useful measurement for evaluating the contractile state of the human heart. (Abstract.) Circulation, 32, Suppl. II, I45.

Oreshkov, V. I. (1968). Phasic analysis of cardiac cycle on the basis of polygraphic tracing. Apex cardiogram, phonocardiogram, and carotid tracing. Fapanese Heart fournal, 9, 332.

Reale, A. (1967). Evaluation of the contractile state of the human heart from the first derivative of the apexcardiogram. Circulation, 36, 933.

Richardson, J. A. (1963). Circulating levels of catecholamines in acute myocardial infarction and angina pectoris. Progress in Cardiovascular Disease, $6,56$.

Rios, J. C., and Massumi, R. A. (1965). Correlation between the apex cardiogram and left ventricular pressure. American fournal of Cardiology, 15, 647.

Rörvik, K. (1963). Apexcardiography, phonocardiography and ballistocardiography - their diagnostic and prognostic significance. Acta Medica Scandinavica, 174, Suppl. 404.

Sjöstrand, T. (1960). Functional capacity and exercise tolerance in patients with impaired cardiovascular function. In Clinical Cardiopulmonary Physiology, 2nd ed., p. 201. Ed. by B. L. Gordon. Grune and Stratton, New York.

Snedecor, G. W. (1959). Statistical Methods. Iowa State College Press, Iowa.

Spodick, D. H., Dorr, C. A., and Calabrese, B. F. (1969). Detection of cardiac abnormality by clinical measurement of left ventricular ejection time. Fournal of the American Medical Association, 209, 239.

Spodick, D. H., and Kumar, S. (1968). Isovolumetric contraction period of the left ventricle. American Heart fournal, 76, 498.

Tafur, E., Cohen, L. S., and Levine, H. D. (1964). The normal apex cardiogram: its temporal relationship to electrical, acoustic and mechanical cardiac events. Circulation, 30, 381.

Tarazi, R. C., Frohlich, E. D., and Dustan, H. P. (1969). Left atrial abnormality and pre-ejection period in hypertension. Diseases of the Chest, 55, 214.

Toutouzas, P., Gupta, D., Samson, R., and Shillingford, J. (1969). Q-second sound interval in acute myocardial infarction. British Heart fournal, 31, 462.

Valori, C., Thomas, M., and Shillingford, J. (1967). Free noradrenaline and adrenaline excretion in relation to clinical syndromes following myocardial infarction. American fournal of Cardiology, 20, 605.

Wallace, A. G. (1968). Catecholamine metabolism in patients with acute myocardial infarction. In Acute Myocardial Infarction: Proceedings of Symposium, University of Edinburgh, 1967, p. 237. Ed. by D. G. Julian and M. F. Oliver. E. and S. Livingstone, Edinburgh.

Weissler, A. M., Harris, W. S., and Schoenfeld, C. D. (1968). Systolic time intervals in heart failure in man. Circulation, 37, 149.

Weissler, A. M., Harris, W. S., and Schoenfeld, C. D. (1969). Bedside technics for the evaluation of ventricular function in man. American fournal of Cardiology, 23, 577.

Wolfe, A. D. (1966). The A wave of the apex cardiogram in idiopathic hypertrophic subaortic stenosis. British Heart fournal, 28 , 179. 